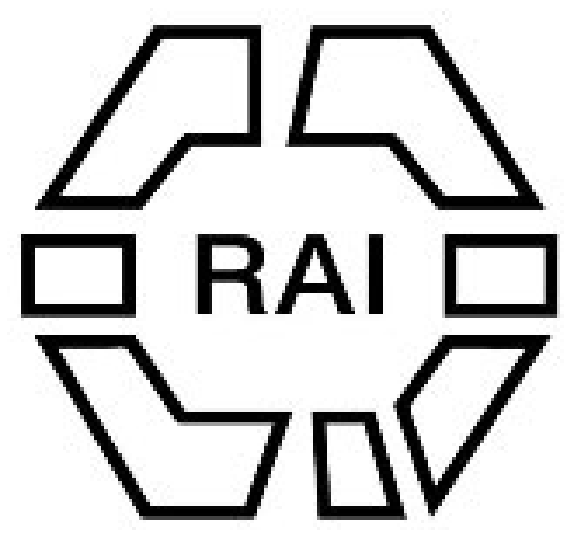

Notes on a Recently Discovered British Camp Near Wallington

Author(s): N. F. Robarts

Source: The Journal of the Anthropological Institute of Great Britain and Ireland, Vol. 35 (Jul. - Dec., 1905), pp. 387-397

Published by: Royal Anthropological Institute of Great Britain and Ireland

Stable URL: http://www.jstor.org/stable/2843075

Accessed: 14/06/2014 21:24

Your use of the JSTOR archive indicates your acceptance of the Terms \& Conditions of Use, available at http://www.jstor.org/page/info/about/policies/terms.jsp

JSTOR is a not-for-profit service that helps scholars, researchers, and students discover, use, and build upon a wide range of content in a trusted digital archive. We use information technology and tools to increase productivity and facilitate new forms of scholarship. For more information about JSTOR, please contact support@jstor.org. 


\title{
NOTES ON A RECENTLY DISCOVERED BRITISH CAMP NEAR WALLINGTON.
}

\author{
By N. F. Robarts.
}

Is bringing under the notice of the Institute the particulars of a British camp which has hitherto remained entirely unknown, and would have remained undiscovered but for some fortunate building operations, I hope to be able to throw some light upon a question which, as well as being of general interest, will interest local antiquaries, and also give some information upon the arts and customs of the date of the settlement. I have termed it a British camp in accordance with general usage, but oppidum or settlement is a more satisfactory description of a place which was evidently residential though fortified by trench, rampart, and probably stockade.

About two years ago I was asked to visit the site of the new buildings now being erected by the Metropolitan Asylums Board at Carshalton-on-the-Hill, to be known as the Southern Hospital, in order to see some geological sections which were being exposed in the course of the excavation of the foundations.

When examining these sections I was informed that some bones had been discovered the previous day in some black earth which had apparently been contained in an old ditch.

On visiting the place, which was situated on the east side of what is now known as "East Isolation Block," I found that the workmen were cutting through some very black soil, in which I detected a fragment of British pottery, which led to my watching the men and seeing several more fragments dug up. I therefore decided to pay further visits to the spot, and eventually I was enabled to get sufficient evidence to prove that a prehistoric settlement had once existed upon the site.

The place is locally known as Stag Field (Ordnance Survey, "Stagg Field"), and lies about a mile south of Carshalton and a little to the west of Oaks Park at Woodcote, and to the east of "Barrow Hedges," a place upon the road from Woodcote to Wallington, where several barrows, which have been recorded, formerly existed. The above road has been supposed to be situated upon the line of an ancient British trackway, and as it runs between the barrows and the camp, which are about half a mile distant from each other, the suggestion that it is an ancient trackway is probably correct.

The exact position of the camp is shown by the station on the Ordnance map, the height 344 feet being the highest point in the camp. The hill upon 
which the camp is situated is principally formed of an outlier of Thanet sand, and stands almost isolated from the surrounding hills, as may be seen by the 300 feet contour line surrounding it on the map, and possesses, in spite of its moderate elevation, a very extensive view upon all sides, particularly towards the Thames Valley, and was therefore admirably adapted for defensive purposes. The fact of the hill being of sand has been of great advantage in tracing the course of the ditch, as the colour of the earth filling the same makes it easily distinguishable from the surrounding sand. Although situated in what is now known as the Hundred of Croydon, and parochially in the parish of Carshalton, the hundred was formerly known as Wallington Hundred, or originally, in Domesday, as Waleton Hundred.

I think I should call attention to what has been written in regard to the present village of Wallington. In their History of Surrey, Manning and Bray write: "It is not improbable that Wallington has formerly been a place of much greater importance than its present appearance would induce us to imagine. It gave name to the hundred in which it stands, which though known only by the name of Croydon Hundred in our modern surveys, the late one of Mr. Linley alone excepted, was at the time of the general survey and is still in our county rate books called the Hundred of Wallington-the very name, indeed, implies as much, which is evidently derived from the Roman vallum."

There will, I think, be little dispute that Waleton, the oldest name, is Walltun or town, and what is more probable than that it took its name from this British eamp situated within a mile of the present village, though no tradition seems to exist of any former settlement.

Roman remains have been found at Beddington to the north-east, and Woodcote to the south, and in view of the disputes which have arisen respecting the site of Noviomagus, which many suppose to have been at or near Woodcote, the presence of this camp almost on the line of the Roman road, which is supposed here to have followed the British trackway, seems to afford considerable evidence of Noviomagus having been probably at or near this camp, if in this neighbourhood at all. It seems to me probable that finding a British camp dominating the road to London the Romans destroyed it and made a station of their own near the place. The remarkable feature about this camp is that it has been completely obliterated, and no tradition attaches to the spot.

The whole surface has been levelled and ploughed, though at present it is meadow land and shows no sign of former arable cultivation. The ditch of the camp and any rampart have absolutely disappeared, and I have been unable to find anything to indicate clearly at what period it was levelled.

I suspect it was in very early times, for the soil filling the upper part of the ditch seems to contain nothing recent, mediæval, or even Roman as far as I can discover. The hill - being isolated the soil would not contain much pottery, etc., unless brought on to it with manure for arable land, and as no pathway even exists through the camp there have probably never been any dwellings near it since it 
was destroyed. The few fragments of Roman pottery found have, I believe, all come from the surface outside the camp, and it will be most interesting if further light can be obtained as to the date at which the levelling took place. The absence of tradition is certainly in favour of its having been levelled at a very remote period.

I must quote one further authority. Thos. Allen, in A. New and Complete History of Surrey, writes "Noviomagus": "This city was undoubtedly the capital of the Bibroci, and upon a fair collation of the various antiquaries as to its real site it appears to have lain under Woodcote Warren, near old Croydon, at a place now called Wallington, in the parish of Beddington in Surrey. Mr. Dallaway inclines to this opinion from an actual investigation of the Roman road from Regnum to Londinium through the weald of the western division of Sussex and Surrey."

"That Woodcote was a camp or a town there can be no doubt, perhaps it might be the former, the town being at Wallington below."

"Following this idea may not Wallington, Vael-ing-ton, vallum or walled town, in the meadow or plain, be the true site of the city."

So far Thos. Allen.

The "ing" in Wallington may be a corruption, and not "ing" a meadow, as the oldest form is Waleton, but there does seem to be a probability that Allen is right, and that Wallington is the walled town of the Bibroci, and this camp their oppidum.

When I first saw the ditch (Fig. 1) the extreme depth was 6 feet, with a width at the top of 12 feet. It was discovered at a most fortunate-spot, for nowhere else have I seen it deeper or so well defined. The section was V-shaped, and, as mentioned before, there is no rampart remaining. The bottom of the ditch was a sharp angle. It was filled to the depth of about 12 inches with very black carbonaceous soil, which extended up both faces until within about 2 feet of the surface, coming slightly nearer the surface on the south side than the north, but this may have been merely local. The soil for the next 3 feet from the bottom was much lighter and contained very few frag-

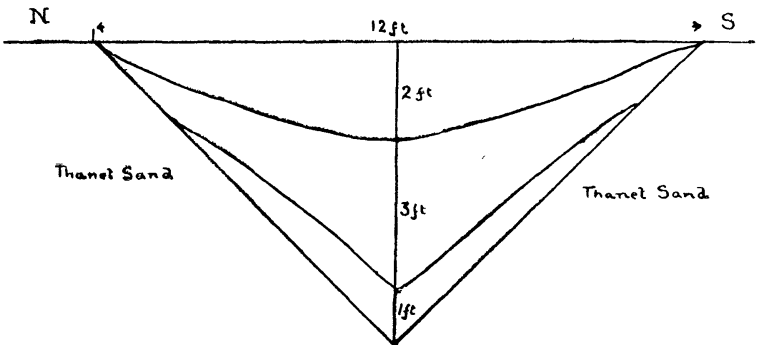

FIG. 1.-SECTION OF DITCH. ments of pottery; whilst the upper 2 feet was indistinguishable from the surrounding soil. I found nowhere in the ditch any Roman remains, whilst almost all the British or Romano-British pottery was in the black earth, but flint flakes were distributed throughout and were present in considerable numbers just under the turf, both within and without the ditch.

Fragments of pottery are not found in the soil in other places below about 
18 inches. Where they are found below plough depth I consider the soil has been somewhat raised by the denudation of the sand from the higher parts of the hill, but pottery is very scarce except in the ditch; doubtless, any left on the surface would soon decay, as the baking is so inferior.

The greatest depth I saw was 6 feet upon the southern side, where the soil was sand-some of the other foundations did not require to be so deep-and at a depth of 2 feet or 2 feet 6 inches it was not so easy to distinguish between the filled-in ditch and the natural soil, but the inclusion of occasional fragments of pottery made it fairly certain that the soil was disturbed. Still I have the impression that the depth was greatest on the south side.

North of the corridor connecting the Isolation Blocks and east of West Isolation Block the ditch appeared to thin out, although the excavations were deep enough to expose it, and I fancy a road entered the camp at this point coming from the trackway. On the south-east is a somewhat damp and marshy piece of land, and I suspect there was originally a spring at this point which supplied the camp with water, probably thrown out by the clays of the Woolwich and Reading beds, an outlier of which lies north and east.

To the north of the camp, at a distance of about 70 feet north from where I consider the ditch runs, is a straight bank running east and west, forming one of the boundaries of the "Stag Field." This bank has been a puzzle to me; the land falls away on the north side, leaving the bank about 2 feet high, whilst on the south the top of the bank is level with the field. There is no ditch, and I am uncertain whether this is an exterior earthwork or has been the accumulation of sand from rain denudation of the hill on the south of an old hedge, and denudation on the north side assisted by the plough. The very gentle slope of the hill here seems hardly sufficient for either or both of these causes to have had the effect of making a bank. Where it has been cut through by a drain I could not be certain of any ditch. It may possibly have formed one side of an ancient cattle-penthe other sides having been levelled.

On my last visit, however, on 10th June, I found slight evidence of the ground about the bank having been disturbed below plough depth.

The V-section of the ditch is, I believe, uncommon, but distinctly British, as at Loughton Camp and Ambresbury Banks, Epping Forest. In reporting on Ambresbury Banks, General Pitt-Rivers observed:- "I have not usually found the bottoms of the ditches of British camps pointed . . . I have always assumed, however, that where the old sides of the ditches are found to stand at an angle of stability of $45^{\circ} \ldots$ that it indicates that the entrenchment was intended to be more or less a permanent work." 1

In the centre of the camp a large number of flints fresh from the chalk were buried. These contained no admixture of pottery or flakes, and were apparently

1 "Report on the excavation of the Earthwork known as Ambresbury Banks-Epping Forest." Trans. of the Epping Forest and County of Essex Field Club, vol. ii, p. 65. 
comparatively recent, and I could not account for them until I came across The History and Antiquities of Carshalton, by George B. Brightling, which makes me think they are connected with a building to which he refers as follows:-

"To the east of Oaks Park is a field called 'Stag Field.' When the twelfth Earl of Derby resided at the Oaks he was acquainted with - Durrant, Esq., of Woodcote, the owner of the field, and at his expense there was erected a wooden tower with a staircase, and on the top a large metal or gilt stag to please the Earl, who could see it from the windows of the Oaks mansion. The field still goes by that name, although the stag and tower have disappeared for some years."

The diameter of the camp, which appears to be almost circular, is about 500 feet, and therefore contains about 4 acres 2 roods. In the centre one or two hearths were cut through, showing burnt pebbles and pot-boilers at a depth of about 12 inches.

Outside the camp, especially to the south-west, mainly in the south part of West Isolation Block, were found remains of much more interest. These were a number of interments marked by ashes and calcined bones, fragments of pottery, and in one instance a calcined skeleton lying, as I was informed by Mr. Schneider, upon its side in a drawn-up position, and on a large slab of burnt stone. Under the stone was a molar of Bos and I think some bones. The skull was almost if not quite entire. When I saw the place the following day the bones had been almost all removed, the skull smashed, and the stone lay broken in fragments. From a portion of jar which was preserved the skull appears to have been that of a child about six years of age.

The stone fragments, however, have been preserved, and prove it to have been the lower part of a saddle-backed corn-crusher, measuring $13 \times 21 \frac{1}{2}$ inches in extreme width and length, and about 4 inches in thickness.

The depth of the hollow upon one face is about one-third of an inch. The stone is apparently a sandstone. With the other burials, of which I saw at least seven or eight, I found no vessels, only fragments of pottery, with calcined flints.

Under the turf adjacent to these burials I found numerous flint flakes, all made from green-coated flints, which are plentiful at the base of the Thanet sand. This green-coated flint appears to have been much preferred in this district for making implements to flints fresh from the chalk; it seems to contain more water, and flakes much more easily.

The flint implements found have been confined to a well-worked round scraper from the surface, a hoe from the upper part of the ditch, a hammerstone from a depth of about 18 inches, a remarkable sickle-shaped implement in the vicinity of the camp, which may have some connection with the cereals to which I shall allude later, and two or three poor scrapers and used flakes. A small cake of copper was found under the turf, but I could not learn if it was associated with a burial; I think it was not, having been lying in the turf.

The moșt interesțing find outside the ditch was a small cup with four handles, 
standing $4 \frac{1}{8}$ inches high, with base 2 inches in diameter (Fig. 2). This was,

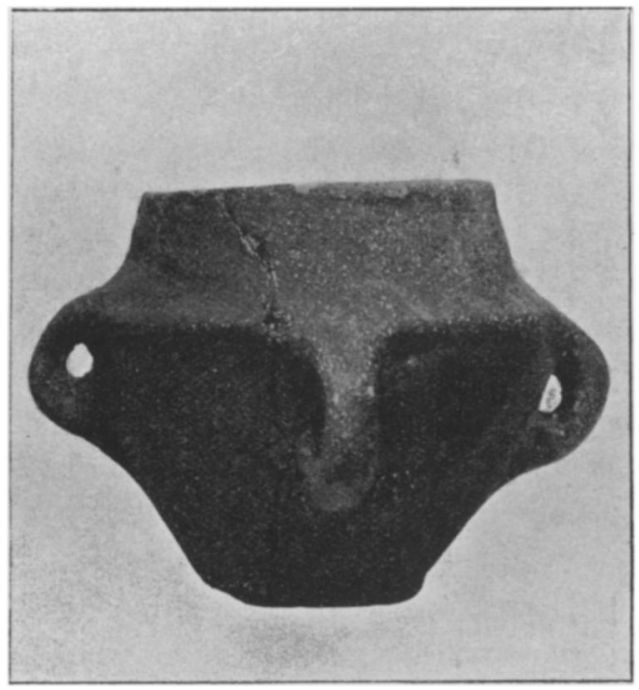

FIG. 2. unfortunately, slightly broken by the workman. Underneath upon the base are some scratches to which I would call attention, as they have a very modern appearance, though the workman assured me he did not do them. He had taken it home and washed it before I saw it, but from his account it contained no bones or ashes. It was found about a foot below the surface.

From the ditch itself I obtained a considerable quantity of pottery, taking into account the comparatively short extent of the opening and my only having been able to visit the works for half an hour or so occasionally, except upon one morning when I was able to watch the work whilst an interesting portion was being excavated. A great deal of pottery was therefore broken up and scattered, though I recovered some from the waste heaps. When found it was all so soft that it was impossible to get even small fragments out without breaking, or several small pots might have been preserved fairly intact.

In several places bones of ox or horse were found, but too decayed for preservation or identification. From the washings of some of the larger vessels, I recovered, in at least three instances, grains of cereals. I have come to the conclusion from the blackness of the soil and these cooking pots that the ditch was used as the general cooking place as being most sheltered from the wind. Two hollow smaller saddle-backed corn-crushers (lower stones) were found, but neither of these are burnt as was the one laid over the skeleton.

One interment, or what I considered to be an interment and not a fireplace, was at a depth of 4 feet. There were ashes, but I could not see calcined bones, two flint flakes, a number of calcined flints and much black earth with fragments of a pot, the exterior diameter of rim, of which I estimate at $15 \frac{1}{2}$ inches. Another similar interment was at a depth of 6 feet, where I observed plentiful ashes and burnt flints with broken pottery from which $\mathrm{I}$ obtained wheat and barley grains.

A third burial was found at a depth of 3 feet 6 inches from which were taken various pieces of pottery. Altogether I noticed some seven or eight burials in the foundations of West Isolation Ward lying to the south, the ditch itself passing through the north-east of the foundations of that block. The interments, therefore, as far as opened chiefly lay to the south-west of the camp, but I noticed one or two others to the north. Whether these were originally all " flat 
graves" or had low barrows over them it is now im. passible to say. The ground has everywhere been levelled.

One specimen of black glossy ware which I have been able partially to reconstruct, resembles ware from the Department of the Marne in the Morel Collection which I believe is attributed to the fourth or third century B.c. ; the height is $3 \frac{1}{2}$ inches, exterior diameter of rim $4 \frac{1}{2}$ inches, height to shoulder $1 \frac{1}{2}$ inches (Fig. 3). Several fragments of similar ware were found.

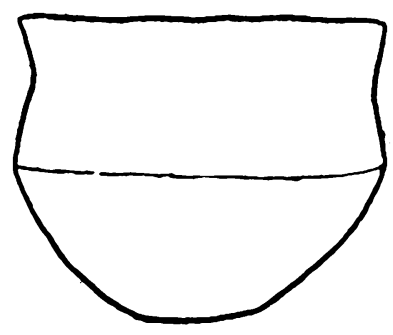

FIG. 3.

The small pieces of Red Samian ware, supposed to belong to the late first century A.D., were found a little distance from the camp, and the same may be said of the fragment of a pedestal urn of the Aylesford type known as "late Celtic," or about B.c. 50 (Figs. 4 and 5). These fragments may therefore be altogether later than the camp itself.

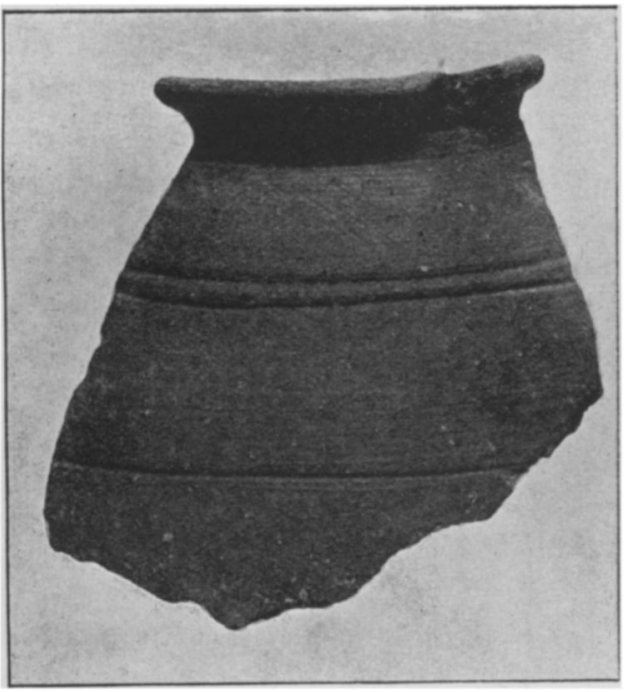

FIG. 4,-FRAGMENT OF URN.

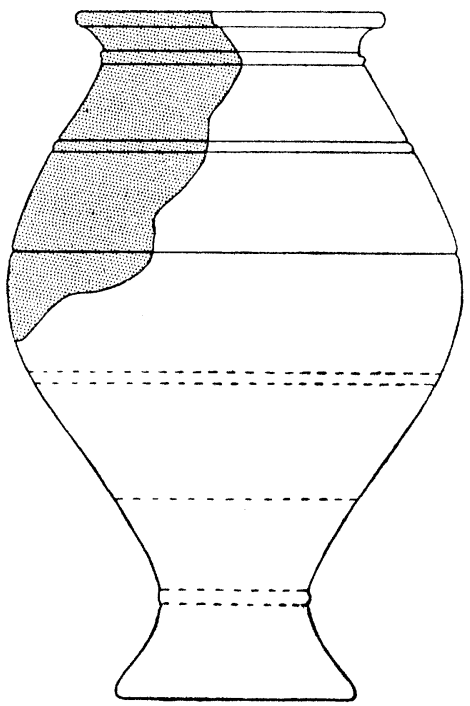

FIG. 5.-RESTORATION OF URN (FIG. 4).

The fragment of a handled jar with " cordon" markings was found, similar to jars found at Colchester. The bulk of the pottery was very coarse, the clay mixed with powdered flint and only partially baked as well as very irregularly fired. Some fragments have finger-nail ornamentation on the rims, others have similar patterns on the shoulder. I have not noticed any with cord markings or incised lines, the only pattern beside the finger-nail ornamentation being reed-like markings on some very coarse ware, which may have been caused by the pots having been built up inside reed baskets when being manufactured. In some places leaves of grass appear to have been in the clay and been burnt out in firing. 


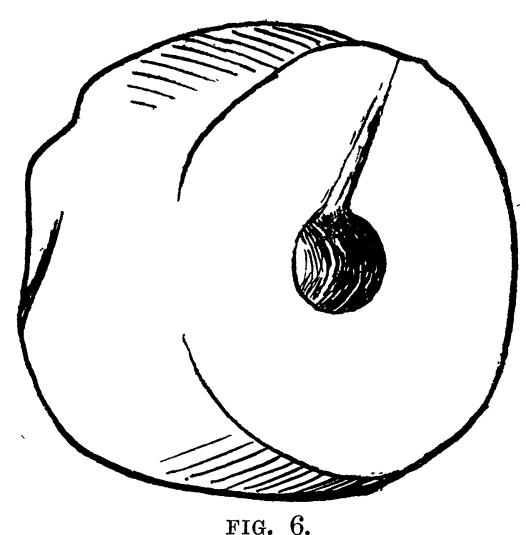

FIG. 6 .

Several loom weights (Fig. 6) were discovered made of slightly baked sandy clay, height 4 inches, diameter 5 inches, with a central hole of about $\frac{3}{4}$-inch diameter. These cylinders show signs of use, the cord which passed through the holes and by which they were suspended has left its mark upon the side of the holes, and one specimen has apparently broken in half from the action of the cord.

But the most curious earthenware consists of fragments of perforated tiles (Figs. 7 and 8) which appear to have measured about

$7 \frac{3}{4}$ inches by 12 inches with a thickness of 1 to $1 \frac{1}{2}$ inches, pierced by holes of about $\frac{1}{2}$-inch diameter. These tiles were numerous and are $I$ believe unique in this country. They all seem to be very much burnt and their use is perplexing. I incline to think they formed movable kilns for pottery making, but so far I have not come across anything but fragments either in the ditch or associated with burials, neither have I found any half-baked pottery, except possibly a fragment of the handle of a jug, to show that the manufacture of pottery was carried on at or near the camp. The presence of very suitable mottled clay in

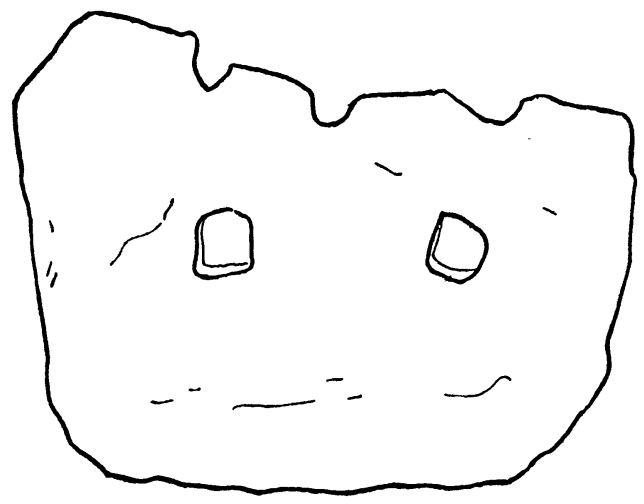

FIG. 7.

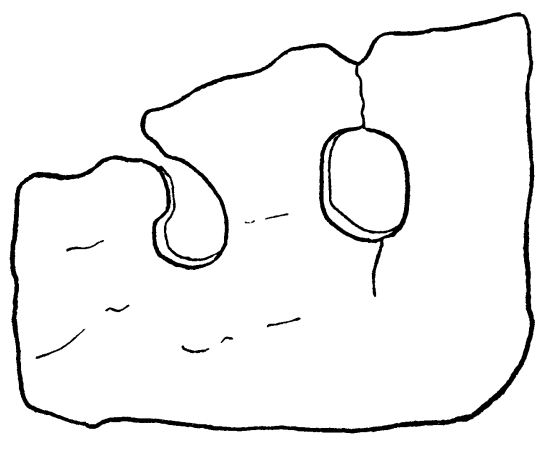

FIG. 8.

the Woolwich and Reading beds only two hundred yards from the camp shows that there was suitable material close by, If these tiles were not used in kilns, they may have been used when cooking. This would account for so many being in the ditch. The use of looms give us some idea of the civilisation of the Bibroci, if indeed I am correct in attributing their headquarters to Waleton. I may point out in support of this conclusion that there is no other known British camp nearer than War Bank in Kent, distant about 10. miles in a direct line or the smaller one at Hayes Common, Kent, also distant 10 miles, or Wimbledon, if this is British, $6 \frac{1}{2}$ miles. 
With regard to the seeds found in washing the pottery, Mr. Clement Reid, F.R.S., has kindly identified same for me and writes as follows: "Burials" (this refers to some from an interment). "Triticum sativum, Hordeum vulgare, carbonised." Whilst from pottery taken from the ditch he finds: "Triticur. sativum (wheat), Hordeum vulgare (barley), Chenopodium Bonus-Henricus (Good King Henry)." Of the latter he says: "Good King Henry is a common weed of cultivation, sometimes used as a pot-herb. It is very common in Roman Silchester, but whether as a weed or cultivated plant I do not know. You have only one seed of it." "Wheat and barley occur together in just the same way at the lake-dwelling of Glastonbury (pre-Roman). The various Roman sites I have thus far examined yield wheat only, barley having seemingly for a time gone out of cultivation. I do not know whether this generalisation will hold."

To sum up, we have near Wallington a British camp, probably the headquarters of the Bibroci, which as the wall-town gave the name to the village of Wallington. If so the town must either have been preserved during the Roman occupation or must have been the Anglo-Saxon name in memory of a Pritish town which had been destroyed. The former hypothesis seems the more probable. On the other hand the latest pottery, if late Celtic, would point to the town having been destroyed by the Romane and the fortifications levelled at that time. The absence, so far, of Roman or mediæval remains in the ditch, point to same having been filled up at a very early period.

The pottery is so very rude, with so little ornamentation that although some is late Celtic, some may be very much earlier, and about this we have at present little evidence for forming an opinion. It requires careîl and systematic excavation of the ditch, which I hope may yet be carried out, to ascertain if there is any order of deposition in the ditch of the two kinds of pottery.

The interments show no trace of urn burial, but only of cremation entire and partial. The fact of no bronze or polished neolithic implements having yet been found, and the copper cake found on the surface outside the camp near the cemetery being the only metallic connection with the Bronze Age, leads me to think that the camp dates from very early Bronze if not late neolithic times, as the various remains may have accumulated for centuries before the Roman invasion. It is clear, however, that the art of weaving was known and agriculture practised, whilst domesticated animals, horse or ox, were kept and slaughtered, their bones, regardless of sanitation, being thrown into the ditch, whilst their flesh with parched and ground corn constituted the food of the inhabitants, who possibly roasted the flesh on earthenware grids.

We can thus give to Wallington the respectable antiquity of 2,200 or possibly 3,000 years, and have increased the probability that a strong Roman station was established in the neighbourhood (possibly Noviomagus) to overawe the tribe whose stronghold they probably destroyed.

In conclusion I desire to acknowledge the assistance I have had in collecting the materials for this paper, especially from Mr. Reginald A. Smith in regard to VoL, XXXV. 
the pottery, Mr. Clement Reid, F.R.S., for information as to the cereals, Messrs. 'Treadwell and Martin, architects of the Southern Hospital, for permission to visit the site, and to their representative, Mr. Schneider, for information and plans ; to Mr. Hooper, clerk of the works, and to the Metropolitan Asylums Board for the loan of various objects for exhibition.

\section{List of Objects Found.}

OBJECTs.

Cake of copper ...

Earthenware loom weights

Earthenware perforated tiles

$\begin{array}{cccc}\text { Bones } & \ldots . & \ldots & \ldots . \\ \text { Tooth } & \ldots . & \ldots . & \ldots \\ \text { Ditto } & \ldots . & \ldots & \ldots .\end{array}$

Earthenware food vessel

Base of vessel .... ... Drinking cup (?) ....

Base of vessel

Rim of vesse

Shoulder of vessel

Earthenware pipkin

Rim and shoulder of vessel

Incense cup

Drinking cup

Mealing stone

Ditto

Interment ....

\section{Position.}

... At a depth of about 6 inches outside the ditch.

... Probably from the ditch. Made of sandy clay, some very indifferently burnt. Cylindrical, 5 inches diameter, $3 \frac{3}{4}$ to 4 inches in height, perforated by hole $\frac{3}{4}$ inch diameter. Worn by cord used for suspension (Fig. 6).

.. Very thoroughly burnt, found in ditch, measuring $7 \frac{1}{4}$ by 12 inches (?), and varying from 1 to $1 \frac{1}{2}$ inches in thickuess. Perforated with holes $\frac{1}{2}$ inch diameter (Figs. 7 and 8).

... From ditch Bos (?).

Ditto Bos.

Equus caballus.

... Probable height 18 inches and 12 inches diameter, ornamented with finger-nail marking on shoulder. Contained carbonised seeds of wheat, barley and "Good King Henry" from ditch.

... Coarse, thick, reddish ware, diameter of base $5 \frac{1}{2}$ inches.

... Blackish, smooth ware, not made on wheel, base $1 \frac{1}{4}$ inches diameter with hemispherical concavity underneath, diameter $3 \frac{1}{2}$ inches at shoulder, height to shoulder $1 \frac{3}{4}$ inches,

total height probably $2 \frac{3}{4}$ to 3 inches.
Thick, coarse ware from ditch, diameter of base $5 \frac{1}{2}$ inches. Contained carbonised wood stc.

... Coarse ware from ditch, with finger-nail pattern.

... Very dark grey ware. Basket or wattle marks on exterior.

... Base of vessel of coarse ware.

.... Dark pottery, rim about $6 \frac{1}{4}$ inches diameter, shoulder $7 \frac{1}{2}$ to 8 inches diameter with burnt wood and grains of wheat and barley, together with burnt or charred wood.

... From a depth of about 12 inches outside camp, four handles, Height $4 \frac{1}{8}$ inches, diameter of rim $3 \frac{1}{4}$ inches, base 2 inches, diameter at shoulder $4 \frac{1}{2}$ inches (Fig. 2).

... Fine black ware. Height $3 \frac{1}{2}$ inches, diameter of rim $4 \frac{1}{2}$ inches, height to shoulder $1 \frac{1}{2}$ inches (Fig. 3).

.... Saddle-backed sandstone (Lower Greensand ?), broken. Oval, probably about 14 inches in length.

Ditto ditto. Width 8 inches, length probably 14 inches.

... Partially calcined skeleton reported to have been lying in drawn-up position upon large calcined mealing stone. Portion of jaw shows skeleton to be that of a child about 6 years of age. Underneath the stone was found tooth of horse. The mealing stone measured $21 \frac{1}{2}$ inohes by 13 inches and 4 inches thick. 
N. F. RobaRTs.-Notes on a recently discovered British Camp near Wallington. 397

OBJECTS.

Sundry eremations

\section{Position.}

Found outside camp at a depth of about 18 inches. With calcined bones and ashes, fragments of pottery, pot boilers and pieces of perforated tiles.

Flint scraper $\quad \ldots . . \quad \ldots \quad \ldots . \quad$ Well-worked neolithic scraper from outside camp.

Flint implement .... .... .... Neolithic hoe ?, probably from ditch.

Numerous flint flakes f... .... From outside camp, depth 6 to 9 inches.

A few fragments of Roman pottery from surface soil.

A considerable quantity of coarse British earthenware and remains of earthenware vessels from ditch. 